Professor Moise has accused me of ascribing to Scott a position he did not take regarding the relationship between peasant communitarian norms and the recruitment of peasants into revolutionary movements. Professor Moise should have noted that the passage in my introduction to which he takes exception is not my conclusion but is one that I have drawn with reference to James Polachek's summary of Scott's argument. Polachek, in turn, refers to Scott's analysis of the Nghe-Tinh rebellion in Annam in 1930-1931 (see Scott, pp. 127-49). Scott situates his analysis of the rebellion in the context of his argument that peasants feel exploited when their "right to subsistence" is threatened and respond to such exploitation by seeking to assert the "norm of reciprocity" (the chapter on "Implications for the Analysis of Exploitation: Reciprocity and Subsistence as Justice" follows immediately the chapter on "The Depression Rebellions"). At the end of his discussion of the Nghe-Tinh rebellion, Scott considers the role of the Indochinese Communist Party and concludes that the party found itself having to adopt "the program of the peasantry" (p. 148), that is, a program based upon "traditional redistributive norms" (p. 149), if it were to make use of the rebellion in its pursuit of its revolutionary goals. Given this conclusion, and the context in which Scott places his argument, it is hardly surprising that Polachek, and also Pierre Brocheux, drew the implications they do.

Moise does raise one theoretical issue, namely that concerning the "rationality" of peasants. While I believe that a significant critique, leading perhaps to a fruitful discussion, might have been made of my use of the notion of rationality in my papers in the symposium, Moise sidetracks such a discussion with an untenable conclusion about my position: "Keyes clearly implies that Scott believes peasant behavior to be guided by moral principles rather than individual (or family) self-interest." I do very much accept that a "moral" approach is rational, and I believe my argument in the introduction and in my other paper bears me out. However, following Weber, I recognize two forms of rationality - "value rationality" and "instrumental rationality." Rather than seeing social action as proceeding from values (which are rational in their own culturally specific terms) or from instrumental means-end calculation, I believe that there is a tension between these two. It is the exploration of such a tension in a particular case that constitutes the essence of my paper in the symposium. I now recognize that because I construe the concept of "moral" differently to Scott I may not have adequately conveyed in the introduction how he subsumes means-end calculations (i.e., "rational" in the Popkin sense) under the notion of moral economy. In my own approach, I disagree with both Popkin, who, I believe, ignores the relevance of values in the shaping of human motivation, and with Scott, who conflates value-rationality with instrumental-rationality. Unfortunately, Professor Moise seems to have mistaken disagreement for misrepresentation.

Charles F. Keyes

University of Wasbington

\title{
On Review of Dissent in Early Modern China
}

I-fan Ch'eng's review of my book Dissent in Early Modern China (JAS 42 [May 1983]:634-35), contains valid criticisms, but I object to his characterization of my thesis and my intentions. Ch'eng exaggerates my claims for modernity and then cites my own recognition of complexity and eighteenth-century conservatism as counter- 
evidence against his misrepresentation of my thesis. Having oversimplified my thesis, Ch'eng proceeds to dismiss it as both tautological and overblown. I may claim too much or too little for the eighteenth century as "early modern," but how can I defend myself against the contradictory charge that I do both at once?

The reviewer took special offense at my first chapter, which was written primarily for the nonspecialist. I believe his charge that I reintroduce "generally familiar secondary literature, especially in English," can only be applied in fairness to that first chapter. Ch'eng is far more accurate and detailed in his discussion of what I did not do than he is in describing what I did. In lamenting my failure to delve more deeply into social history, he ignores the bulk of my book, which discusses Rulin waishi from a variety of intellectual perspectives.

I agree with Ch'eng that "rigorous research and finer analysis are in order," but there is much to be said for simple accuracy in a book review.

Paul Ropp

Memphis State University

\section{A Response to Paul Ropp}

If "simple accuracy" in reading the thesis of his book is Paul Ropp's main concern, his letter has done little to help us achieve it. Besides easy charges of "exaggeration" and "oversimplification," Ropp makes no attempt to show how his "real" thesis differs from the "misrepresented" one. While an author can always appeal to complexity after unresolved tension is found in his work, the question is whether his "recognition of complexity" is reflected in the conceptualization of his thesis.

As to the charge of contradiction, I should mention that the "too much, too little" dichotomy does not exist in my review, and that any work can be - if found to be so-at once "tautological and overblown," for it may be overblown in effort and tautological in effect.

The first chapter is a scapegoar. My impression is that many parts of the book read like review essays. And since the book contains clear claims to be "social history," especially in the introduction, the reviewer is not to be blamed for criticizing its failure to fulfill the original promise.

\section{I-FAn Ch'eng Howard University}

\section{On the Review Article, Stability and Prosperity in Hong Kong}

Being accused of "oversimplifications, distortions, deliberate omissions, and even outright denials of known facts" by Ming K. Chan is an unexpected honor. It clearly indicates that my book Hong Kong: Capitalist Paradise is somehow different from the ones he has chosen to praise in his review article (JAS 42 [May 1983]:589-98).

Indeed it is! I stress such salient facts as exceptional growth rates, creation of modern industrial and service sectors, expansion of employment, rise of per capita 